\title{
Effect of Rice's Biochemical Component Variation Induced by Reproductive Water Deficit on the Traditional Bread (Ablo) Quality
}

\author{
Roseline T.M. Bleoussi ${ }^{1}{ }^{*}$, Innocent Yaou Bokossa ${ }^{1}$, Celestin C.K. Tchekessi ${ }^{1}$, \\ Pivot A. Sachi ${ }^{1}$, Anayce Djogbe ${ }^{1}$, Jultesse Banon ${ }^{1}$, Karl T. Assogba ${ }^{1}$ and Mamadou Fofana ${ }^{2}$ \\ ${ }^{1}$ Unité de Recherche en Sécurité Sanitaire des Aliments (URSSA), Laboratoire de Microbiologie \\ et des Technologies Alimentaires (LAMITA) de l'Université d'Abomey-Calavi, 04BP 1107, \\ Cotonou, Benin \\ ${ }^{2}$ Laboratoire de Physiologie du Centre du riz pour l'Afrique, Ibadan, Nigéria \\ *Corresponding author
}

Keywords

Ablo, biochemical composition, quality, rice, water deficit.

\section{Article Info}

Accepted: 25 September 2016 Available Online: 10 October 2016
Ablo is a wet bread slightly salty-sweet, steamed, originally prepared from a semiliquid paste fermented corn widely consumed in West Africa. Nowadays, corn is substituted by rice in this food manufacturing process. The objective of this study is to determine the effect of the variation of local rice's biochemical components induced by reproductive stage water deficit on the quality of ablo. The methodology consisted in conducting a survey in some localities in South Benin followed by the production of ablo's samples from two varieties recently developed (ARICA 4 and NERICA 1) and the physicochemical, microbiological and sensory analyses of the samples. The survey revealed that ablo production is exclusively female's activity which is usually inherits from relatives. Also, the results showed that three production processes of ablo depending on the raw materials used, namely, corn, rice or mixture of corn and rice. The statistical analysis revealed that there was no significant difference $(\mathrm{P}>0.05)$ between $\mathrm{pH}$, titratable acidity, and the yield of all of the ablo samples. However, it was found that ablo samples from non-stressed grain contained more dry matter $(31.92 \%$ to $33.14 \%)$, more total sugar $(10.59 \%$ to $10.78 \%$ ) and produced more foam during the fermentation process than the ablo samples obtained from grain collected from stressed plants. Also, the study showed that the fermentation process is achieved by yeasts and lactic bacteria, which tend to multiply more in ablo samples obtained from non-stressed samples. Ablo can be considered as a hygienic food because of the absence of pathogens due to its acidity and its cooking.

\section{Introduction}

In the Western Africa, maize, rice, millet and sorghum are the most consumed cereals. In Benin, maize is a stable food crop in both urban and rural areas.
Consumption of maize is estimated at 85 kg/capita/year (Nago, 1997; FAO, 2010). Its consumption rate vary according to the regions of the country; in the Northern part 
of Benin the consumption rate is less than 30 $\mathrm{kg}$ per capita per year while in the Southern and the central parts of the country the consumption rate is 100 and $150 \mathrm{~kg}$ per capita per year respectively (Hounhouigan, 1994; FAO, 2010). Formerly, rice was consumed only during special events such as festivals, wedding, naming ceremonies and funerals. Nowadays, this cereal is a staple food in Benin due to its quick and easy preparation. Rice consumption rate was estimated at an average of $14 \mathrm{~kg}$ per capita per year in 1999 (INSAE, 2000), it has experienced a growth rate of $46 \%$ between 2000 and 2005 and reached our days more than $40 \mathrm{~kg}$ per capita per year (FAO, 2011). Rice is used in several traditional recipes, the most known of these recipes in the west africa is ablo. Ablo ("bread in the Mina language") is a slightly salty-sweet wet bread, steamed (Nago and Hounhouigan, 1998), prepared originally from a semiliquid paste fermented maize. Ablo was known as a street food that can be consumed during breakfast, lunch or dinner time. These days, this food is served in hotel restaurant, especially during popular celebrations (Ahokpe, 2005; Aholou-Yeyi, 2007, Bokossa et al., 2013). To date, three cooking methods of ablo are known; the traditional method described by Nago and Hounhouigan (1998) which exclusively use maize as raw material, the modified method descripted by Ahokpe (2005) which use only rice as raw material and intermediate method descripted by Aholou-Yeyi (2007) mix rice-maize is used as raw material for this method. Ablo's quality and its acceptability by consumers strongly depend on the quality of the raw material and manufacturing process. In the pass, the scarcity of local rice imposed the use of imported rice which is costly as compared to local produced rice in the process of cooking ablo. These days with the increase of local rice production, imported rice is being replaced by local produced rice. However, due to climate change, rice production is subject to water stress which induces changes in physical and biochemical components on rice grains. The objective of this study is to determine the effect of changes in biochemical components of the grains of some local produced rice varieties induced by water stress occurred at reproductive stage on the quality of ablo.

\section{Materials and Methods}

\section{Characteristics of the raw material}

Two interspecific varieties of rice (ARICA4 and NERICA1) were used. The two rice varieties were grown under optimal growing condition where they were well watered throughout their life cycle and under stress condition where they were subjected to severe reproductive water deficit that induced significant changes in their grain's biochemical components (table 1).

\section{Investigation}

A survey was conducted in four localities namely; Cotonou, Porto-Novo, Comè and Bohicon in Benin. A total of one hundred and twenty (120) individuals were interviewed. The survey consists in collecting, sociocultural information concerning those who usually are involved in cooking the Ablo, the nature of the raw material used and the reason of the choice of a specific raw material.

\section{Production and chemical analysis of ablo samples}

Ablo samples were developed following the improved technology described by AholouYeyi, (2007) (figure 1). Fermented dough and ablo samples were taken in three repetitions, for the study of the 
fermentation's dynamics and analyses of nutritional and sensory quality. For fermentation dynamics, fermented dough samples were taken during the duration of fermentation at $0 \mathrm{~h}, 2 \mathrm{~h}, 4 \mathrm{~h}$ and $6 \mathrm{~h}$ according to an arithmetic result of $2 \mathrm{~h}$.

\section{Determination of growth (change in height of the foam)}

Initial and final dough front levels were marked with horizontal lines at the level of fermentation materials. At the end of fermentation, the deviation or variation in height $(\mathrm{cm})$ representing the lifting of the dough (the level of foam) was measured using a ruler.

\section{Yield}

Dough's yield, was determined according to Decock and Cappelle (2005) method

\section{Physicochemical analysis}

The dry matter content was determined according to the method of AACC, 44, 15 A (AACC, 1984), from $5 \mathrm{~g}$ of fresh sample, by differential weighing, after crossing the Heraeus T 5042 oven at $105^{\circ} \mathrm{C}$ for $72 \mathrm{~h}$. The $\mathrm{pH}$ and titratable acidity were determined according to the modified Nout method (AOAC, 1984). Total sugars were determined by the Luff-Schoorl method (Lees, 1968), after extraction of the sugars with ethanol at $40 \%(\mathrm{v} / \mathrm{v})$, defecation using Carrez 1 and 2 Carrez reagents, the inversion of sucrose then the titration of total sugars with the $0.1 \mathrm{~N}$ sodium Thiosulphate.

\section{Microbiological analyses}

Microbiological analyses consisted in counting the total mesophilic flora (NF ISO 4833, 2003) on PCA (Oxoid CM 0325) at $30^{\circ} \mathrm{C}$, lactic bacteria on MRS-agar CM 0361 at $30^{\circ} \mathrm{C}$, yeasts and molds (NF ISO 215272, 2008) on Sabouraud Dextrose Agar (Oxoid CM 0041) at chorampphénicol $(0.05 \mathrm{~g} / \mathrm{l})$ at $25^{\circ} \mathrm{C}$, total coliforms (NF ISO 4832 (V 08-015), 2006) and thermotolerant coliforms (NF ISO 4832 (V08-060), 2009) on VRBA-Oxoid CM 0107 (Violet Red Bile Agar) at $37^{\circ} \mathrm{C}$ and $44^{\circ} \mathrm{C}$ respectively. Lactic bacteria and yeasts have been chosen because they are the ones which provide mainly the fermentation of cereals, while total and thermotolerant coliforms reflect the hygienic quality of the product.

\section{Sensory analysis}

The sensory analysis of ablo samples was conducted using a panel of 33 tasters. They were randomly selected and trained for the purpose. The ranking of the ablo samples was based on criteria such as taste, color, texture, and acceptability. Scores ranging from 1 to 5 have been attributed to these criteria according to the methodology described by Larmond (1977) quoted by Bokossa et al., (2011).

\section{Statistical analyzes of data}

The Excel software was used to perform the calculations. Analysis results were processed using Minitab 14.0 software that permitted to make analysis of variance (ANOVA) and Tukey's test for comparison of means. The significance level of $5 \%$ is selected $(\mathrm{p}<0.05)$.

\section{Results and Discussion}

The results of the survey revealed that the production of ablo is an exclusively female activity. Also, it this business was found to be a family affair and that the methodology was transferred from mother to daughter or other close relative. The results of the survey 
are consistent with those of Dossou et al., (2011), Banon (2012) and Bokossa et al., (2013). These authors stated that in Benin, the ablo production technology was transferred from mother to daughter from one generation to another. Three ablo manufacturing processes were identified at the end of the investigation. These manufacturing processes differ mainly by raw material used; an original process using maize, a modified process using rice as raw material and an intermediate method using a mixture of maize and rice as raw material. The most widely used method by the surveyed transformative is the modified process. The toughness and the too long duration of the original process forced the majority of producers to gradually replace the rice by maize. Ablo production time varies from one process to another, but also based on the experience of the producer since the technology is not standardized. The average cooking time of ablo is six (6) hours when the mawe is already available. The imported rice is the type of rice used by most of the transformative surveyed. Hundred percent (100\%) of the transformative explained the use of imported rice because of the non-availability of local rice.

In order to compare their nutritional value, following parameters were determined; potential of Hydrogen $(\mathrm{pH})$, titratable acidity, yield in dough and dry matter. The statistical analysis of the results showed that there was no significant differences ( $p>$ 0.05 ) between the $\mathrm{pH}$, titratable acidity, and the dough's yield of the two categories of ablo (ablo cooked using stressed and nonstressed grain) (table 2). However, it was found that samples of ablo from nonstressed grain contained more dry matter, total sugar and produced more foam during the fermentation than those obtained from stressed grains (table 2). $\mathrm{pH}$ values of the ablo samples cooked using the stressed grains were between 4.94 and 4.98; These values are higher but not significantly ( $\mathrm{p}>$ $0.05)$ than the $\mathrm{pH}$ values of ablo samples from non-stressed grain which vary between 4.91 and 4.95 (table 2). Nout et al., (1989) and Adjigbey-Tasas (2003) showed that below $\mathrm{pH}=5$, life becomes impossible for the pathogens. The values of the titratable acidity of the two categories of ablo varied between 1.24 and $1.27 \%$ (table 2). The values obtained were close to those obtained by Dossou and al., (2011).

The initial dough yield averaged $178 \%$, indicating the semi-liquid state of ablo paste, in accordance with the classification of Decock and Cappelle, (2005). The dry matter content varied from 31.92 to $33.14 \%$ from fermented pulp non-stressed grain and $25.52 \%$ to $27.25 \%$ percent from stressed grain paste. These values are lower than those reported by (Decock and Cappelle 2005) (i.e. 57.2 to $59.9 \%$ of water content, or $41.1 \%$ to $42.8 \%$ dry matter) on a similar Chinese steamed bread dough. The average values of dry matter in ablo's samples from non-stressed grain was significantly $(p<0$, $05)$ superior to the average values of the dry matter from ablo's samples of stressed grain, no matter the variety of rice. The difference between the rate of dry matter is justified by the change of amylose's rate in stressed and non-stressed grain. A significant difference $(\mathrm{p}<0.05)$ was also between the two categories of ablo regarding the variation of foam. Ablo samples from non-stressed grain produced more foam during the fermentation compared to samples from non-stressed grain (table 2). According to (Ahokpe, 2005), the amount of foam produced would be in relation with the textural quality of ablo, therefore, ablo from non-stressed grain will have a good texture compared to ablo from the stressed grains. 
Int.J.Curr.Microbiol.App.Sci (2016) 5(10): 849-857

Table.1 Biochemical characteristics of varieties

\begin{tabular}{lccc}
\hline Varieties & Amylose (\%) & Protein (\%) & Dry matter (\%) \\
\hline ARICA4 (well-watered) & 27.33 & 9,02 & 86.84 \\
ARICA4 (stressed) & 18.29 & 11,00 & 89,14 \\
NERICA1 (well-watered) & 28,32 & 9,41 & 83,29 \\
NERICA1 (stressed) & 18.72 & 10.83 & 87.57 \\
\hline
\end{tabular}

Table.2 Physicochemical characteristics of the different types of ablo table

\begin{tabular}{lclllll}
\hline Ablo type & $\mathrm{pH}$ & $\begin{array}{l}\text { Titrable } \\
\text { acidity } \\
(\%)\end{array}$ & $\begin{array}{l}\text { Height } \\
(\mathrm{cm})\end{array}$ & $\begin{array}{l}\text { Yield } \\
(\%)\end{array}$ & $\begin{array}{l}\text { Dry matter } \\
(\%)\end{array}$ & $\begin{array}{l}\text { Total } \\
\text { sugars }(\%)\end{array}$ \\
\hline $\begin{array}{l}\text { Ablo based ARICA4 } \\
\text { well watered }\end{array}$ & $4.91 \pm 0.03$ & $1.27 \pm 0.02$ & $3.64 \pm 0.05$ & $175 \pm 0.03$ & $33.14 \pm 0$. & $10.78 \pm 0$. \\
$\begin{array}{l}\text { Ablo based ARICA4 } \\
\text { stressed }\end{array}$ & $4.98 \pm 0.02$ & $1.24 \pm 0.01$ & $2.93 \pm 0.17$ & $180 \pm 0.02$ & $\begin{array}{l}68 \\
27.25 \pm 0 .\end{array}$ & $\begin{array}{l}58 \\
8.64 \pm 0.29\end{array}$ \\
$\begin{array}{l}\text { Ablo based } \\
\begin{array}{l}\text { NERICA1well } \\
\text { watered }\end{array}\end{array}$ & $4.95 \pm 0.03$ & $1.27 \pm 0.01$ & $3.65 \pm 0.02$ & $179 \pm 0.02$ & $31.92 \pm 0$. & $10.59 \pm 0$. \\
$\begin{array}{l}\text { Ablo based NERICA1 } \\
\text { stressed }\end{array}$ & $4.94 \pm 0.03$ & $1.26 \pm 0.02$ & $2.96 \pm 0.08$ & $179 \pm 0.02$ & $25.52 \pm 0$. & $8.96 \pm 0.33$ \\
P value & & & & & 59 & \\
\hline
\end{tabular}

Fig.2 Evolution of lactic bacteria during the fermentation

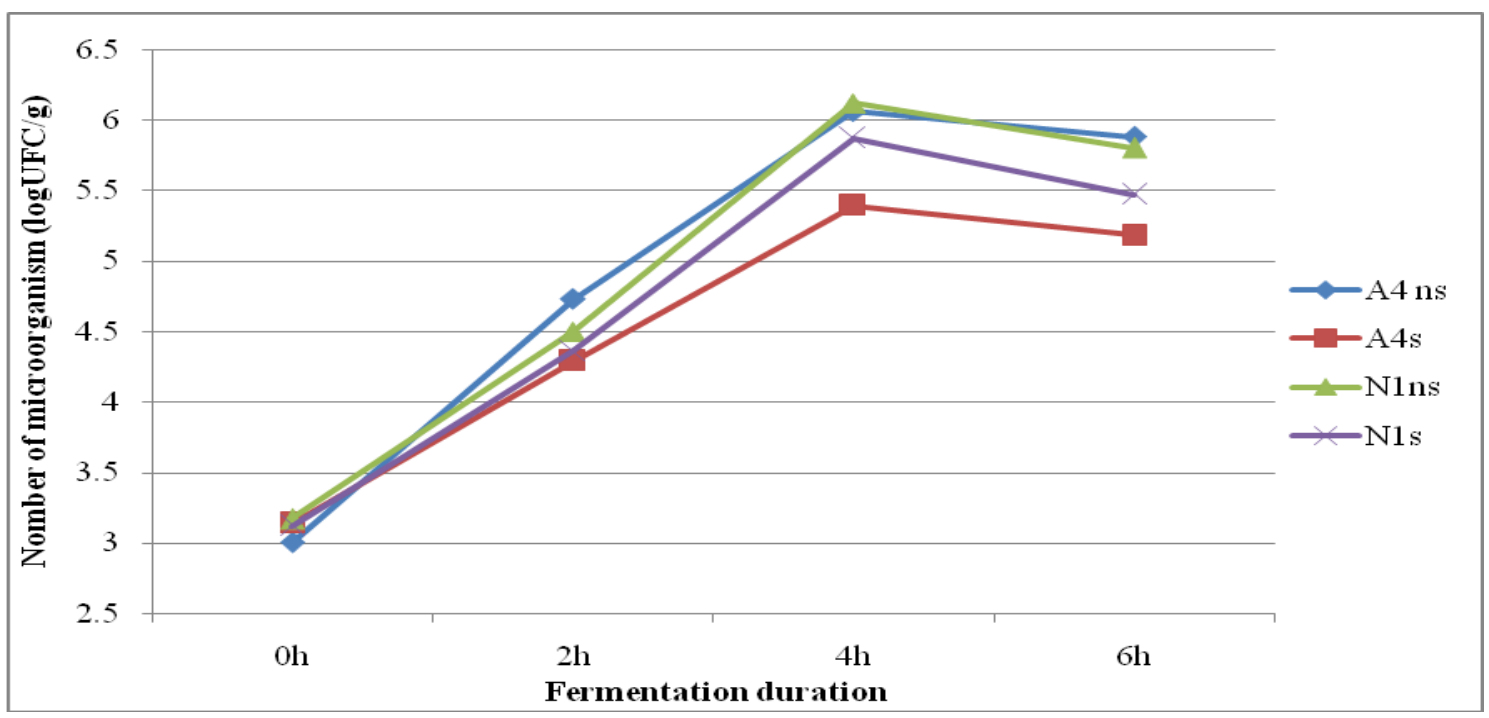

Note $: \mathrm{ns}=$ non stressed $; \mathrm{s}=$ stressed 
Fig.1 Diagram of production of ablo following the modified process
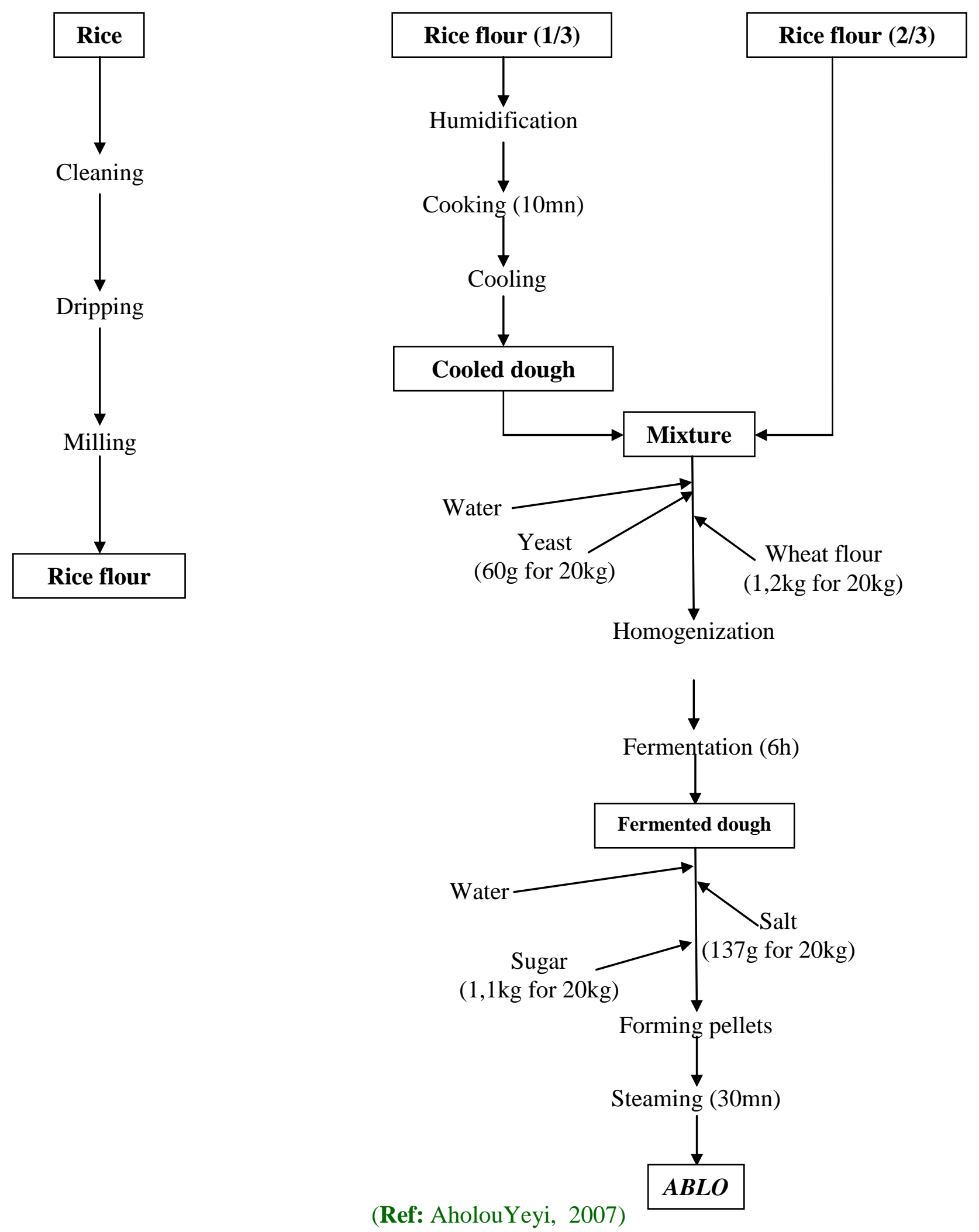
Fig.3 Evolution of yeast/fungi during the fermentation

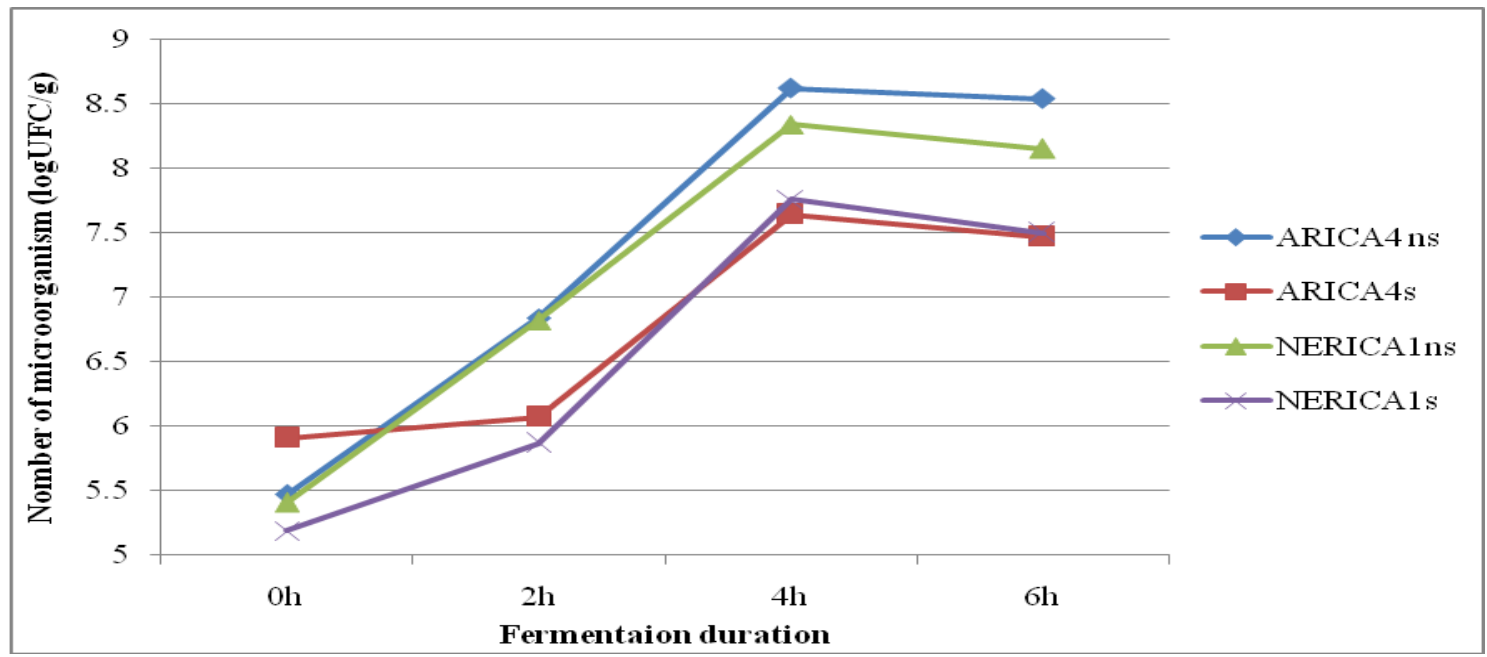

Note: $\mathrm{ns}=$ non stressed; $\mathrm{s}=$ stressed

Fig.4 Comparison of the sensory parameters of different types of ablo

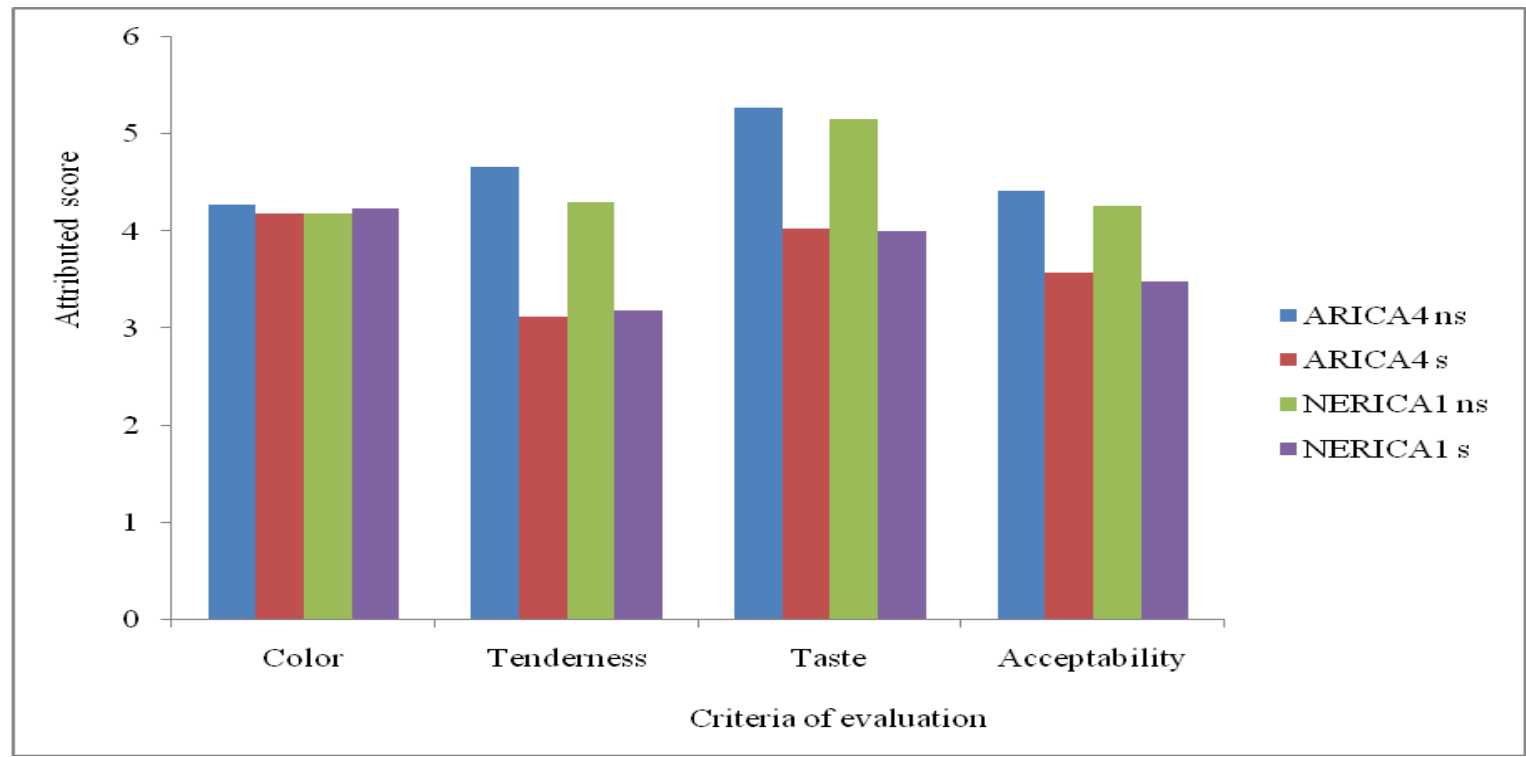

Note: $\mathrm{ns}=$ non stressed; $\mathrm{s}=$ stressed

The results showed that yeast/mold and lactic bacteria increased gradually until the fourth hour regardless to the type of ablo (figures 2 and 3). This increased could be related to the logarithmic phase of microorganisms' growth, which corresponds to the stage of maximum output of carbon dioxide $\left(\mathrm{CO}_{2}\right)$, from the oxidation of fermentable sugars; then comes a slight slowing in the growth of the microorganisms from the fifth to the sixth hour. However, during the entire fermentation process, the microbial load (in yeast/mold and lactic bacteria) was more important in the ablo cooked from the grains of non-stressed plants as compared to samples from the grains of stressed plants (figure 2 and 3 ). This may be due to the reduction of biochemical composition that broke the multiplication of microorganisms during the fermentation of ablo of the stressed grains. The Aerobic mesophilic flora of ablo samples was relatively high but did not vary depending on the treatment receive by grain 
(stressed or well-watered). The results showed the absence of total and thermotolerant coliforms in all ablo's samples developed; these results are consistent with those of Dossou et al., (2011). These results indicate that according to the hygienic qualities, the standards were respected during the manufacturing process.

The results (figure 4) reflected the sensory analysis of the two categories of the ablo adjusted. The figure showed that the two categories of ablo were identical in terms of color regardless the variety. The water stress didn't influence on this feature of ablo. Mean while, based on the tasters' responses, the ablo samples developed from the grains of non-stressed plants were softer and taster. Results of sensorial analysis showed that all of the ablo manufactured were accepted by the tasters. However, panelists preferred the ablo from non-stressed grain. Also, the results showed that ablo from ARICA varieties have been slightly more appreciated by the tasters than from the NERICA varieties (figure 4).

In conclusion, Ablo is a food that has much value in West Africa and especially in Benin, it is originally produced from corn, but hardness and too long duration of this original process lead to technological changes, resulting in partial or total substitution of maize by rice especially in urban areas. The changes in the biochemical composition (mainly the decline in the rate of amylose) of rice have a negative influence on the quality of ablo.

\section{References}

AACC. 1984. Approved Methods of the American Association of Cereals Chemists. $8^{\text {th }}$ ed. St Paul. MN. USA. $53 p$

Adjigbey-Tasas, R. 2003. Contribution à la valorisation des aliments traditionnels béninois: étude comparative de deux technologies à base de sorgho malté pour la production de gowé. Thèse d'Ingénieur Agronome, FSA/UAC. Bénin. $110 \mathrm{p}$.

Ahokpe, K.F. 2005. Valorisation des aliments traditionnels locaux : Evaluation des procédés traditionnels de préparation de "ablo", une pâte fermentée cuite à la vapeur. Mémoire pour l'obtention de la maîtrise professionnelle en Biotechnologies agroalimentaires. Laboratoire de Microbiologie et de Technologies Alimentaires. Faculté des sciences et techniques, Abomey-Calavi. Bénin. $51 \mathrm{p}$.

Aholou-Yeyi, A.M. 2007. Evaluation du système technique artisanal de production d'Ablo, un pain cuit à la vapeur. Thèse d'Ingénieur Agronome. FSA/UAC. 69p.

Banon, S.B.J. 2012. Evolution de la flore microbienne au cours de la fermentation d'un produit alimentaire fermenté du Bénin : cas du Ablo. Mémoire de Master. FAST/UAC. Bénin. 57 p.

Blandino, M.E., Aseeri, A., Pandiella, S.S., Cantero, D., Webb, C. 2003. Review Cereal-based fermented foods and beverages. Res. Food Int., 36: 527-543.

Bokossa Yaou, I., Banon, J.B.S., Tchekessi, C.K.C., Dossou-Yovo, P., Adeoti, K., Assogba, E. 2013. Evaluation socioéconomique de la production de ablo, une pâte de maïs fermentée du Bénin. Bulletin de la Recherche Agronomique du Bénin, Numéro spécial, Productions Animales \& Végétales et Economie \& Sociologie Rurales, P. 35-40.

Bokossa Yaou, I., Tchekessi, C.K.C., Dossou-Yovo, P., Egounlety, M., Dossa, R.M. 2011. Substitution partielle du lait en poudre par le lait de soja pour la production du yaourt. 
Bulletin de la Recherche Agronomique du Bénin. 69: 48-55.

Decock, P., Cappelle, S. 2005. Bread technology and sourdough technology. Review. Trends in Food Sci. Technol., 16: 113-120.

Dossou, J., Osseyi G.E., Ahokpe, F.K.K, Odjo, S.D.P. 2011. Evaluation des procédés traditionnels de production du ablo, un pain humide cuit à la vapeur, au Bénin. Int. J. Biol. Chem. Sci., 5(3): 953-967.

FAO, 2010. Perspectives de récolte et situation alimentaire. FAO. Rome. Italie. $40 \mathrm{p}$.

FAO. 2011. FAOSTAT. http:// faostat. fao.org.consulté le 20072016

Hounhouigan, D.J. 1994. Fermentation of maize (Zea mays L.) meal for mawè production in Benin: Physical, chemical and microbiological aspects. $\mathrm{PhD}$ Thesis, Agricultural University, Wageningen, The Netherlands, 99p.

INSAE. 2000. Statistiques de consommation du riz au Bénin. Annuaire statistique; Ministère de l'économie et des Finances. Cotonou. Bénin. 56 p.

Lees, R. 1968. Laboratory Handbook of Methods of Food Analysis.

Nago, C.M. 1997. La transformation alimentaire traditionnelle du maïs au Bénin: détermination des caractéristiques physico-chimiques des variétés en usage ; relations avec l'obtention et la qualité des principaux produits dérivés. Thèse de doctorat
d'Etat Es-Science. Université Paris VII Denis Diderot. 571p.

Nago, C.M., Hounhouigan, D.J. 1998. La Transformation Alimentaire des Céréales au Bénin. Les Publications du CERNA. 150p.

NF ISO 21527-2, 2008. Microbiologie des aliments, Méthode horizontale pour le dénombrement des levures et moisissures. Partie 2 : technique par comptage des colonies dans les produits à activité d'eau inférieure ou égale à $0,95.9 p$.

NF ISO 4832 (V 08-015), 2006. Microbiologie des aliments, Méthode horizontale pour le dénombrement des coliformes. Méthode par comptage des colonies obtenues à $37^{\circ} \mathrm{C} .6 \mathrm{p}$.

NF ISO 4833, 2003. Microbiologie des aliments, Méthode horizontale pour le dénombrement des micro-organismes. Technique de comptage des colonies à $30^{\circ} \mathrm{C}$ sur PCA. $19 \mathrm{p}$.

NF ISO4832 (V08-060), 2009. Microbiologie des aliments, Dénombrement des coliformes thermotolérants par comptage des colonies obtenues à $44^{\circ} \mathrm{C}$. Biokar diagnostics Violet Red Bile Agar (VRBA). 4p.

Nout, M.J.R., Rombouts, F.M., Havelaar A. 1989. Effect of accelerated natural lactic fermentation of infant food ingredients on some pathogenic microorganisms. Int. J. Food Microbiol., 8: 351-361.

\section{How to cite this article:}

Roseline T.M. Bleoussi, Innocent Yaou Bokossa, Celestin C.K. Tchekessi, Pivot A. Sachi, Anayce Djogbe, Jultesse Banon, Karl T. Assogba and Mamadou Fofana. 2016. Effect of Rice's Biochemical Component Variation Induced by Reproductive Water Deficit on the Traditional Bread (Ablo) Quality. Int.J.Curr.Microbiol.App.Sci. 5(10): 849-857.

doi: http://dx.doi.org/10.20546/ijcmas.2016.510.093 